\title{
Yelling into the Silence and its Echos. Czech Shoah Poetry Written till 1960s and its Reception
}

\begin{abstract}
Balík Štěpán, Yelling into the Silence and its Echos. Czech Shoah Poetry Written till 1960s and its Reception. "Poznańskie Studia Slawistyczne" 12. Poznań 2017. Publishing House of the Poznań Society for the Advancement of the Arts and Sciences, pp. 29-45. ISSN 2084-3011.

The literary reflection of the Shoah in Czech war and post-war poetry is very limited. Only a few non-Jewish poets have ever returned to this theme (e.g. František Halas, Jiří Koláŕ, Jaroslav Seifert, Jan Skácel, Karel Křepelka, Radek Malý). Additionally, literary "testaments" of Jewish authors (Karel Fleischmann, Pavel Friedmann etc.) resulted in only two collections of poems entirely dedicated to the suffering of the Jews during the Nazi oppression (Ota Reich and Michal Flach). On the other hand, there are several books of poetry about Lidice and suffering of the Czech people during the World War II by Viktor Fischl, Karel Šiktanc, Libuše Hájková, Miloš Vacík and others. After the war there were only Jaroslav Seifert and Jiří Koláŕ among well-known poets who refered to the Shoah in a more significant way. Seifert created a figure of a Jewish girl, Hendele, in his collection of poems Koncert na ostrove (Concert on the Island), which develops the literary narration of the Shoah. Jiř́i Koláŕr referred to the Shoah repeatedly, however, he only had a limited chance to publish his work. As a result of this fact, the reception of Czech post-war poetry about the Shoah is almost absent. In my article, I concentrated on some reviewers' remarks that have already been published since the war-time and other reflections of this kind such as editions of books by Jiři Orten, Hanuš Bonn, Jiři Daniel. A hypothetical reaction on the Shoah verses by Pick's cabaret audience or Halas's anonymous poetic obituary paying tribute to Jiří Orten are rather specific sorts of reception. The critical reflection of Kolár's work in the context of the mass murder commited during the WW II is exceptional. However, the specific motifs of the Shoah were significantly focused on only in recent years by three foreign reviewers (Leszek Engelking, Hanna Marciniak and Anja Golebiowski). Czech Shoah poems printed or reprinted in Jewish periodicals (e.g. annual "Židovská ročenka", published since 1954) represent a commemorative function, even though sometimes with informative commentaries. They miss any analytical aspect.
\end{abstract}

KeYwords: Czech poetry; the Shoah; Reception; Czech martyrdom; Jewish martyrdom 
In comparison with the Polish literary context ${ }^{1}$, there are just a few poems about the Shoah in the Czech poetry. Only few well-known poets write about the theme repeatedly (e.g. František Halas, František Gottlieb, Jiří Koláŕ, Jaroslav Seifert, Jan Skácel, Karel Křepelka or Radek Malý). Most of the poets published only a single poem about the Shoah (e.g. Josef Hiršal, František Hrubín, František Branislav, Konstantin Biebl). Some of the authors could be called occasional writers, who create a piece of art in order to resist the Nazi oppression and the vision of a possible forthcoming violence or death (Ota Reich, Pavel Friedmann etc.). The work of Jewish poets - written also after World War II - might be interpreted as a result of prisoners' art therapy (e.g. Karel Fleischmann, Pavel Fischl, Dagmar Hilarová).

The only two collections of poems devoted to the Shoah are Kverty terezinského ghetta (Blossoms of Terezín) and Ohlednutí z veliké dálky (A Look Back from a Faraway Place). The author of the first collection Ota Reich (1914-1942/1943) could not receive a degree in law due to the Nazi closing down the Czech university system (autumn 1939). The poems were written in Terezín in 1942, and before Reich was deported with his parents to Auschwitz, he managed to send them to his sister, who lived outside the ghetto. After the WW II, the book of poems was published posthumously by writer, translator and collector of art Emanuel Lešehrad (1877-1955), who edited the received collection of poems, created the title and added some information on the personal and literary context (Reich 1946).

The poems from the aforementioned collection Ohlédnutí z veliké dálky (A Look Back from a Faraway Place), which was prepared to be published by the author and the Shoah survivor Michal Flach (1920-2008) in 1946, was not published until 1997. Surprisingly, there is no

${ }^{1}$ In the book Poeci i Szoa. Obraz Zagłady Żydów w poezji polskiej (Poets and the Shoah. Picture of the Holocaust in Polish Poetry), Natan Gross argues, that the Polish Holocaust literature is the third richest one following the Yiddish and Hebrew literature. Moreover, he claims there is no other national literature, which introduces five anthologies of the Shoah poetry, no fewer than thirty collections of poems almost entirely with this theme and several dozens of single poems (Gross 1993: 7). Further on, Gross's enumeration does not involve pieces of art and poetic "documentary" published in the compiled anthology of Jewish-Polish non-professional poets Tango tez śpiewajcie muzy. Poetyckie dokumenty Holokaustu (Sing the tango of tears, muses. Poetic documentaries of the Holocaust; Keff 2012). 
critical reflection of his work in any literary magazines. Only Markéta Hošíková in her bachelor's paper analysed mainly the formal aspect of Flach's poetry, which deals only with the persecution of Jews during the WW II and its aftermath (Hošíková 2009). She noticed the variation of verses in a poem called Terezín and Čekání (Waiting) from the Auschwitz part (Hošíková 2009). It is these variations which are present in the poem Terezin in the annual "Židovská ročenka" in the 1980s. However, the verses are ascribed to an unknown Jewish boy ("Báseň neznámého židovského chlapce z r. 1944") ([Flach] 1987/1988: 137). Flach's authorship is not mentioned for political reasons as he lived in emigration in the USA from 1946.

Another noteworthy example is the poetry of Dagmar Hilarová (1928-1996), who was interned under her maiden name Dagmar Berzetti in the Terezín Ghetto from March 1943 until May 1945. Her collection of poems Sto barev má duha (The rainbow has hundred colours) written probably in the 1960 s, is still in the manuscript ${ }^{2}$. Paradoxically, in the form of a book, only the German translation Hundert Farben hat der Regenbogen: Gedichte (Hilarová 1966) was published thanks to the cooperation of the then representative of Jewish community Rudolf Iltis and East German poet Günther Deicke. Several poems from the collection became a part of her prose Nemám žádné jméno (I have no name), published posthumously thanks to her son (Hilarová 20103; Hilarová 2012). In the 1980s her verses were published in the Dutch version in the cooperation with the well-known writer Miep Diekmann, whose artistic contribution to this project is nevertheless very small (Hilarová, Diekmann [1980]). Hilarová herself explained the genesis of the book in her testament to make sure future Czech literary historiographers would understand her work properly ${ }^{4}$ :

První kapitola knížky „Nemám žádné jméno” vznikla už v roce 1962, kdy jsem se psaním začala profesionálně zabývat, ale materii $\mathrm{k}$ tomuto tématu jsem nosila $\mathrm{v}$ hlavě už od konce druhé světové války. Poznala jsem, co je fašismus a začala jsem se touto tematikou literárně zabývat, hlavně v poezii a drobných prózách. $\mathrm{Z}$ mozaiky př́iběhů s autobiografickými prvky vzniklo dílo, které se mi podařilo dokončit až těsně před

\footnotetext{
${ }^{2}$ The database of the National Library refers to it, but it is not available (v: $<$ www.nkp.cz $>$ ).

${ }^{3}$ It was published in a limited number of copies as a facsimile of the manuscript.

${ }^{4}$ Technical translation of the extracts by Alexandra Šípová.
} 
vydáním [tj. holandským v roce 1980 - Š.B.]. Dávala jsem je paní Krijtové k překladu po částech (Hilarová 2012: 86-87) .

In the artistic work of both authors Reich and Hilarová, the severe life conditions in the ghetto are emphasized. Reich's Jiří Wolker-like poetry is rather traditional and could be handled as an art document. Hilarová's verses reveal thinking of a young girl and they express the attitude of defiance and even revenge in the future. Although the verses of Hilarová and Reich were published in "Židovská ročenka" (Hilarová 1968-1969: 117-118; Reich 1982-1983: 87) and some Hillarová's poems were also put to music, both authors are almost completely unknown to the Czech literary historiography.

Another fact that deserves attention is the absence of books of poetry referring to this theme in the Czech literature written after 1945, and consequently the lack of reception regarding single poems that were included in either literary or Jewish periodicals. In addition, some pieces of art were not published because they were not suitable for the post-war policy or they were allowed to be printed in a marginal minority annual called "Židovská ročenka", which is a very valuable source of material of this kind.

In conformity with Czech martyrdom, there are more books of poetry that show suffering of Czech people in WW II. Viktor Fischl and Karel Šiktanc published Mrtvá ves (The Dead Village; 1943 during emigration in England and 1945 in Czechoslovakia) and Heinovské noci (Heine Nights, 1960) about Lidice ${ }^{6}$. The same point of view is represented in the post-war edition of revolutionary leaflets of poetry Dech davu (Breath of the Crowd). Paradoxically, one of the leaflets Bratr Jan (Brother John, 1946) written by Nora Fried (Norbert Fried, after 1946 Frýd) included no hints of Jewish context; however, Frýd and his murdered brother were affected by racial

5 "The first chapter of I have no name was created as early as in 1962, when I started to write professionally, but I had been thinking about this subject since the end of WW II. I got to know what fascism is and started to write about it, especially poems and short prose pieces. The mosaic of stories with autobiographic elements became the base for a book that I managed to finish just before its publication [i.e. the Dutch publication of 1980 - Š.B.]. I handed it over in parts to Mrs Krijt to have it translated".

${ }^{6}$ The village was chosen to be destroyed and people killed or sent to camps by the Nazi due to a false suspicion that one of Reinhard Heydrich's assassinators was connected with the place. 
persecution. The emphasis on this perspective is also evident in Libuše Hájková's Balady zatracenců (Ballads of the Damned, 1946) 7 and Miloš Vacík’s Malá kalvárie (Little Calvary, 1946), both collections of poems.

Oldřich Kryštofek in his review Další z koncentračních tábori̊ (Another one from the Concentration Camps) is very harsh to such authors in general, however, the strongest criticism is targeted on naive Hájková's poetry:

Nemine ani týdne, aby pohotoví nakladatelé nevychrlili další dávku publikací o koncentračních táborech a věznicích. Žel se tak děje přečasto bez kritického uvážení a porady. (...) To, co spáchala perem (...) zaslouží nejpř́ísnějšího odsouzení. Jen a jen popisnost, snadná a laciná rethorika, nadužívání silných výrazů. Do nemohoucích veršů nacpala koncentrační thematiku, které předeslala silácké věnování s řečnickými tirádami - jsme přesvědčeni, že o takové verše se jí nikdo neprosil - stoudnost autorky i nakladatelského lektora byly by spíše na místě. A k tomu to vyšlo na křídovém papíře s ilustracemi - je v těch Adlerových kresbách opravdu všechno - od musulmanů až k plačícím matkám - což opravdu u nás cudnost v těchto věcech je neznámou pevninou? (Kryštofek 1946: 4) ${ }^{8}$.

Dealing with the Shoah literature from 1939, i.e. from the Nazi occupation, I could name several authors, who thematized the strenghtening prohibitions (Orten's Zákazy in the diary Žíhaná kniha - 27.10.1940) (Orten 1993: 225), feelings of insecurity, closeness of possible death in their sometimes very general lyrical verses. Hints of the Shoah could be seen in the writings of Jiří Orten (Jiří Ohrenstein, 1919-1941), Hanuš Bondy (1913-1941), Jiří Daniel (František Schulmann, 1916-1945).

The best known Jiří Orten, the leader of his poetic generation, published his last works under the pseudonyms Jiří Jakub or Karel Jílek. In the

${ }^{7}$ The collection of poems was rediscovered and discribed by Reinhard Ibler (Ibler 2014: 25-35), however, the book is devoted to the Czech martyrology and the Holocaust atributes (e.g. musulman) play role of a mere staffage.

8 "Not a week passes before ready publishers bash out another publication on concentration camps and prisons. Unfortunately, it's happening too often without any critical consideration and consultation. (...) What she did with her pen (...) deserves the strongest rejection. Mere descriptiveness, simple and cheap rhetoric, overuse of strong expressions. She stuffs the concentration subject in her impotent verses introduced with a swaggering dedication in her rhetorical rant - we are convinced that nobody asked her for such verses - the author's and the proofreader's shame would be more suitable. On top of that it was printed on glossy paper - in those Adler's drawings there is almost everything - from Musulmans to crying mothers - don't we really have any modesty in these things here in our land?" 
war-time, reviewer Jaroslav Červinka assessed his poetry very positively. Shortly after a "review" Žid vede mladé básníky (A Jew is leading young poets) in the pro-Nazi periodical "Árijský boj", which contained a part called "Reflektor" ("Spotlight") based on reports denouncing Jews, was published. This humiliating text focused on revealing the author's name (Jews were not allowed to publish anymore at that time) and his family background (cf. Brabec 2009: 170, 173).

Vracíme se k našemu článku „Pěvci národa na rozcestí”, otisknutém v 30. čísle „Árijského boje". Článek končili jsme citátem z úvahy šéfredaktora dr. Jaroslava Křemena, který apeloval na mladou generaci básnickou, aby opustila chmurnou meditativní poesii a vrátila se $\mathrm{k}$ činorodému životu. [...] Věc je skutečně velmi trapná pro naši básnickou generaci! V době, kdy se vede velký zápas proti Židům zjišt'uje se, že v čele českých básníků stojí Žid, který přirozeně není nadšen novými poměry, a který proto by se nejraději vrátil do lůna mateřského, aby tam přečkal světovou konflagraci. Aféra Žida Ohrensteina je však především aférou oficiálních českých kritiků. Jak je možné, že oficielní česká kritika se nezmínila o židovském původu Karla Jílka, a že nechala ho stát v čele mladé básnické generace?!? (Anonymous 1941: 5) 9 .

Shortly after that, Jiří Orten was accidentally hit by a car in Prague street and he died soon (1.09.1941). In the literary magazine "Kritický měsíčník", firstly, a famous poet František Halas published a cryptonymical poetic mourning paying tribute to the poet Za básnikem (Mourning for the Poet $)^{10}$, secondly, Václav Černý wrote the anonymous obituary Torzo... (Torso...; Černý 1941: 293-296).

V měsíci sklizně

bled a natažený

9 "We are returning to our article Singers of the nation at a crossroads published in the $30^{\text {th }}$ edition of "Aryan fight". We finished the article with the quotation from the reflexive essay of the chief editor, dr. Jaroslav Křemen, who appealed to the young generation of poets for abandoning sombre meditative poetry and returning to an active life. (...) The whole thing is very embarrassing for our poetic generation indeed! In the time of a great fight against Jews it has been found out that the leader of Czech poets is a Jew, who, certainly, is not happy about the new situation, and who therefore would rather go back to his mother's womb where he could wait out the global conflagration.

The affair of Ohrenstein the Jew is above all the affair of the official Czech critics.

How come the official Czech critics have not mentioned the Jewish origin of Karel Jílek, and allowed him to be the leader of the young generation of poets?!?"

${ }^{10}$ After the war the poem was published under the changed title Za Jirim Ortenem (Mourning for Jiří Orten; Halas 1957: 374-376). 
ztracen pro utrpení

leží ten básník sotva olistněný

a Musa cuká křídlem trčícím

(...)

Až v katedrálách plouti budou ryby tento básník vyvolán jménem bude

(Halas 1941: 264, 266) ${ }^{11}$.

However, in 1942 the magazine was discontinued by the Nazi authorities, and was renewed only after the occupation. In the post-war time, Václav Černý wrote a literary portrait of Jiří Orten Básnický profil Jiřiho Ortena (Černý 1945: 196-206), which is supplemented with several his poems from still unpublished collection of poems. Apart from publishing their poems in periodicals, works of Hanuš Bonn (1947) and Jiří Orten (1947) were published posthumously by Václav Černý in a form of a book. Although Jiř́ Daniel's contribution was also appreciated shortly after the war (Daniel 1947: 35; Červinka 1947: 50-52), the publication of his poems, correspondence, diary etc. was delayed for more than fifty years (Daniel, Toman 1998; cf. Toman 2002: 139-160). Orten's work could be published in the less oppressive times. A critical edition of his entire work was completed only after 1989.

František Gottlieb (1903-1974), who was a member of Czechoslovak foreign army and then a clerk of the exil Ministery of Foreign Affairs in Great Britain, released his collection of poems Dvojí nástup (Double line-up) under pseudonym Josef Goral in London in 1942. The extended version came out in Czechoslovakia in 1946. Both editions mostly focus on two Jewish homes of the lyrical subject: Palestine and Czech lands, however, there are a few hints at the Shoah.

Návrat

Až vrátíme se, budem procházet

chvějícím sloupořadím stínů

a krví budem zardělí

těch, které nepotkáme.

11 "In the month of the harvest / pale and stretched out / lost for suffering / the poet lies freshly covered in leaves / and the Muse twitches her sticking wing / (...)/ Once fish swim in cathedrals / the poet's name will be called". 
Až vrátíme se, budem vzpomínkou.

I k sobě dojdem z minulosti

(Gottlieb 1946: 63) ${ }^{12}$.

Despite the fact that the Jewish motifs were reflected by the wellknown Czech reviewer Antonín Matěj Píša, he concentrates on different issues of Gottlieb's poetry, e.g. formal level.

Lyrik židovského rodu a nadto sionistického smýšlení, prožíval Gottlieb od počátku s neobyčejnou intensitou - blízek v tom uctívanému Ot. Fischerovi - problematiku svého původu a jeho údělu, která se mu arci za uplynulých let nově utvářela jednak tragickým losem jeho souvěrců, jednak vzdáleností od české domoviny a jejím osudem (Píša 1946: 4) $)^{13}$.

A very similar attitude appeared twenty years later. In Jaroslav Seifert's (1901-1986) Koncert na ostrové (Concert on the Island) Jewishness and the Shoah theme is represented by the figure of a little girl Hendele. Reviewers mentioned the theme of Jewish suffering, however they are more interested in the sudden change of Seifert's poetic language. Hence, his harmonic verse was substituted by a more prosaic expression, which is more suitable for the theme of WW II (Brabec 1966: 5; Kostroun 1966: 145-146; Píša 1966: 266-270; Pešat 1991: 190, 195-196).

Seifert's collection is a personal encyclopaedia of death. In such an eschatological concert even the figure of the lyrical subject is placed somewhere on the edge of life and death. Both Karel Kostroun and Zdeněk Pešat stressed the phenomenon of human transiency (lidská dočasnost) in Koncert na ostrově (Kostroun 1966: 145-146; Pešat 1991: 191).

In the part called Šñurkami oprátek (Through the strings of nooses) the theme of the Shoah culminates. It is demonstrated in the poem Pisen o Hendele (The Song of Hendele) by a quoted nursery rhyme and a dry

12 "Homecoming / When we come back, we will walk / along the shaking colonnade of trees / flushing in blood / of those we will not ever meet. // When we come back we will be a memory. / We can find even ourselves through the past".

13 "A lyricist of a Jewish origin and moreover of a Zionist thinking, from the beginning Gottlieb experienced with an extraordinary intensity - in this respect he was close to admired Ot. Fischer - the issues of his origin and its fate, which had been forming over the past years partly by his fellow-believers drawing the short straw, partly by the distance from his Czech homeland and its destiny". 
commentary added to it. The verses at the end of the poem show a picture of traumatised post-war mind of the lyrical subject.

(...)

na koho to slovo padne,

ten musí jít pryč

A padlo na ni

$(\ldots)$

Po tolika létech

někdy se vracívá,

ale musím být sám

a musím se přidržet židle.

Protože pojednou zmizí,

a v dálce se ozve pláč,

pak zoufalý výkřik

a nakonec hrobové ticho

(Seifert 1965: 74-75) $)^{14}$.

Kostroun argues that The Song of Hendele is a suitable example of Seifert's ability to create something out of nothing (Kostroun 1966: 146). According to Píša, "the motif of Jewish destiny at that time, either agonizingly incarnated in a particular creature of a girl called Hendele, or wholly uttered in a visionary note of master lamenter's lament" 15 appears for the first time in Seifert's work.

14 “" $(\ldots)$

One, two three,

out goes she

And she went

(...)

After so many years

sometimes she comes back

but I have to be alone

and hold onto the chair.

As she suddenly disappears,

and there's crying from afar,

then a desperate scream

and dead silence at last".

15 “(...) motiv tehdejšího židovského údělu, at’ rozdíravě vtěleného v konkrétní bytůstku dívčí Hendele nebo úhrnně vysloveného vizionářskou notou žalmistrova žalozpěvu" (Píša 1966: 267). 
A different type of reception can be seen in Jiří Robert Pick's (1925-1983) 7 kytic pro buvola (7 Bunches of Flowers for the Buffalo, 1966). This book probably reflected the author's activity in a cabaret. Pick founded the cabaret Paravan and in the late 1960s the cabaret Au. Some of his pieces play with words, use puns and even deliberately sound silly. Thus, the presence of gallows humour is very shocking. However, it could be seen as a way how he coped with the personal and family experience of the Holocaust survivor. (He was a teenage prisoner of ghetto Terezín and his father was murdered in Auschwitz.) An extreme example is the following poem Nedávno jsem byl v bratrském Polsku (Recently, I Have Been to Brotherly Poland; incipit), in which silence and banality make the background for the non-accented, but, omnipresent theme of the Shoah. The consternated cabaret audience play the role of the perceiver and thus the potential reviewer.

Navštívil jsem mimo jiné také Osvětim (dříve Auschwitz).

Je to menší město s velikým chemickým závodem, vybudovaným

z větší části za Němců.

S několika neprŕiliš zajímavými obchody.

S průměrným polským hotelem.

A uprímně řečeno na ulicích mají dost bláta.

Ale přesto na Osvětim nikdy nezapomenu.

Koupil jsem tam totiž v jednom obchůdku ženě mřížkové

punčochy.

Ovšem přese všechnu radost, kterou jsem z toho měl, zůstal

ve mně tak trochu hořký pocit.

Není to poněkud hloupé, když musím jezdit kupovat

mřižkové punčochy do Osvětimi, městečka

ležícího 60 kilometrů západně od Krakova?

A to ještě v soukromém obchodě! (Pick 1966: 103) ${ }^{16}$.

This Pick's prosaic writing in verses reminds the reader of the style of Jiř́ Koláŕr (1914-2002), who described the collection Černá lyra (The Black

16 "Besides other places I visited Osvětim (former Auschwitz). / It is a smaller town with a big chemical plant, whose biggest part was built under the German rule. / With a few quite uninteresting shops. / With an average Polish hotel. / And, to be honest, their streets are rather muddy. / Yet I will never forget Osvětim. / It is because I bought / lattice tights for my wife in one of the shops. / Nevertheless, no matter how happy I was about it, / a bitter feeling remained. / Isn't it a bit stupid if I have to go shopping / for lattice tights to Osvětim, / a town 60 kilometres west of Krakow? / In a private shop on top of that!". 
Lyre), which is a part of his book Vršovický Ezop (Aesop from Vršovice), in the author's postscript as an attempt to write "the history of human wickedness, finished with the evidence from concentration camps" (in the original: "Celá sbírka měla být dějinami lidské podlosti, ukončenými svědectvími z koncentračních táborů"; Koláŕ 1966: 182). As I have already written about the motifs of the Shoah in Kolár's work in Czech Bystanders Writing Poetry about the Shoah. Different Ways of Poetic Languages in the First Post-War Literary Reactions (Balík 2016: 139-143), I will limit myself here to the critical reflection which relates to the Jewish extermination.

Jan Grossman, a friend of Jiří Kolář's, analysed his work in several texts. In the afterword Horečná bdělost Jiřiho Koláře (Jiř́i Kolář's Feverish Watchfullness) to Kolář's book Náhodný svědek (An Accidental Witness) in 1964, Grossman explained the author's prosaic style (prozaizace) he used in the description of the "undescribable" experience gained during the war (Grossman 1991: 369). He even commented on Kolář's verses-reports about a concentration camp, known by Grossman from his diaries, which had not been published yet. He stated that its quality might be questionable, but we could not call it non-poetry. It was not a bare formal modification of a prozaic text. Moreover, he defined this poet's creative act as "an extreme edge of an experiment, which is not formal, but it concerns the very essence of poetry" (in the original: "krajní meze experimentu, který není formální, ale který se týká samotné podstaty poezie"; Grossman 1991: 373). Grossman also underlined Koláŕrs litanic style, which is so significant for his work in general. In his opinion, Kolář's litany has two features: firstly, the enumerative style, conjoined with variations of authentic facts, which reveal new meanings and relations allowing them in this way to become saint, monumental; secondly, the aggressive and domineering pathos (Grossman 1991: 366-367).

In the 1960s, also other reviewers as Zdeněk Heřman (Heřman 1967: 92), and above all Jan Trefulka (Trefulka 1968: 62-63) and Miloš Vacík, who both wrote a short article taking in consideration the whole author's work (Vacík 1969: 5), analysed Koláŕrs experimental poetry style in the context of the experience of mass killing and concentration camps. Koláŕ's authentic poetry was mentioned as an appropriate tool in his rewriting the authentic documents (e.g. related to the Nazi atrocities) by Karel Milota in his imaginary interview with the poet (Milota 1967: 98). In a set of 
four short reviews on the aforementioned book of poetry Vršovický Ezop, only Karfík's remark is noteworthy. In the very last sentence, he compared Kolár's contribution to the theme of the Shoah with a work written by the member of literary group Grupa 47 Peter Weiss: "Skutečnost, že Kolár psal Černou lyru deset let před tím, než šokoval svým oratoriem Peter Weiss ${ }^{17}$, by námi mohla otřást, ale to by si jí byl musel alespoň dnes někdo všimnout"18 (Burda, Moldanová, Steklač, Karfík 1967: 50).

In Frynta's afterword of Prometheova játra (Prometheus's liver), published first abroad in the 1980s, but written already in 1969, the critic focused on formal novelty of the "hearkening poet" ("naslouchající básník") in the context of the Czech literary tradition imparting to the theme of the Shoah a marginal meaning (cf. Frynta 1990: 215).

After 1989, Koláŕr's work in the context of the Shoah was commented on in other critical texts. Vladimír Karfík, who later wrote a book Jiř́ Kolár, emphasized the moral attitude of the subject, which is present in Kolář's work in general. Paraphrasing final verses of Mistr Sun (Master Sun) Karfík stressed that the task of a poet is thus "to read from the darkest signs of the fate" ("číst z nejtemnějších znamení osudů"), to be "where the life is the cruellest" (být tam, "kde je život nejkrutější"), and "with those, whose life is the cruellest" ("s těmi, jejichž život je nejkrutějšś" (Karfík 1994: 60). This attitude can be found in all Kolář's poems, where he wrote about the Shoah, i.e. Dny v roce (Days in a Year), Prométheova játra (Prometheus's Liver), Očitý svědek. Deník z roku 1949 (The Eye Witness. The Diary of 1949), Černá lyra (The Black Lyre), for the first time partly published in the book of poetry Vršovický Ezop (Aesop from Vršovice), and also in his last text Záznamy (Records; cf. Balík 2016: 139-143), however, verses devoted to the theme of the Shoah are always presented in the context of cataclysms, genocides and cruelties occuring in the history of the whole world.

${ }^{17}$ Weiss's theatre play Die Ermittlung. Oratorium in 11 Gesängen (1965) was already translated into Czech under title Přelíčení. Oratorium o jedenácti zpěvech by Bedřich Becher in 1966. About motifs of the Shoah in Koláŕ's theatre plays, v. Agata Firlej's article From Report to Mythus. Jiř́ Kolářs Plays as Creative Transformation of the Shoah Testimonies.

18 "The fact that Kolár wrote Černá lyra ten years before Peter Weiss shocked with his oratorio could have given us the shivers, but only on understanding that there must have been someone today who had noticed it". 
In Michal Bauer's study Kolárovy dějiny lidstva jako dějiny bolesti a hravosti (Koláŕ's History of the Human Kind as a History of Pain and Joy; Bauer 2005: 33-55) ${ }^{19}$, which is a part of a book interview Z každého $z$ nás postupem let něco mizí. Rozhovor s Jiř́m Kolárem (Something of Each of Us Will Vanish with Every Passing Year. The interview with Jiří Kolář), or in Jiří Holýs literary survey Židé a šoa v české a slovenské literature po druhé světové válce (Jews and the Shoah in Czech and Slovak Literature after the Second World War (Holý 2011: 19), the theme of the Shoah sticks to the statement already mentioned by Jiři Kolár himself about "the history of human wickedness" (Bauer 2005: 38, 46, 49; Holý 2011: 19). In addition, in the context of Koláŕr's textual and visual art, Bauer stressed the therapeutic and autotherapeutic dimension of his work (Bauer 2005: 41). The crisis of literature after the world has experienced the cruelties of the WW II is - according to Bauer - solved by Koláŕ's oscillation between words and silence (Bauer 2005: 55).

An innovative perspective was presented by two Polish critics Leszek Engelking and Hanna Marciniak. Although they both point out the motifs of the Shoah in various texts and pieces of visual art by Jiří Kolár and Tadeusz Różewicz, their attitudes are slightly different. In his contribution Laleczki na sprzedaż. Zabawa w Holokaust $i$ handel z Holokaustem (Puppets for Sale. The Holocaust Game and Business with the Holocaust), Leszek Engelking (Engelking 79-94) uses the term "holokaustowe decorum" ("Holocaust decorum"), which means a way of taboo writing about the Shoah. Since such a modus was misused in the economic, political and mass cultural sphere, Engelking stated that the artistic feature forced - sometimes with drastic means - by Kolář, Różewicz and also Václav Burian and Zbigniew Libera (LEGO) are chosen in order to reveal the manipulation with the experience of the Shoah and to enable the new perception regarding the commented problem.

In her study "Píśi tyto rádky a prosím Boha, aby se dostaly do pravých rukou... ”. Jiřri Kolár - Tadeusz Różewicz: poetika sekundárního svédectví (,I Am Writing These Lines and I Am Begging the God so that They Reach

\footnotetext{
${ }^{19}$ This text is a modification of two Bauer's earlier articles Kolár̆ovy způsoby zachycení dějin bolesti a hravosti (Bauer 2001a: 23) and Jiři Kolár̆: Očitý svědek v zemi mrtvých / Očitý svědek ze zemé mrtvých (Bauer 2001b: 6-7), which are connected here.
} 
the Right Hands...". Jiř́i Kolář and Tadeusz Różewicz: Poetics of Secondary Witness), Hanna Marciniak used a term "secondary witness", which accentuates the phenomenon of artists, who did not experienced the Shoah personally, but it is the object of their work. Marciniak showed how Kolár and Różewicz modified the original records, testimonies along with the documentary photography. She also questioned the stable interpretation of archival materials or the narration in verses about an object, which was owned by the Holocaust survivor - a small knife (Różewicz). The shifts ("witness as the montage" or "rewriting the Shoah") are interpreted as a deliberate artistic attempt to disrupt the passive and contemplative perception of the Shoah and to offer a provocation, which aims for affective excitement and reflection (Marciniak 2014: 214-239).

Another attempt to compare Koláŕ's work with the Polish literature is an article written by German literary historiographer Anja Golebiowski. In her contribution Der Holocaust und seine kulturellen Folgen. Reflexe des Holocausts im Oeuvre von Jiři Kolár und Marek Hłasko (The Holocaust and Its Cultural Aftermath. Reflection of the Holocaust in Work of Jiri Kolár and Marek Hłasko), she pointed out that the motifs of the Shoah appeared in the work of both authors repeatedly, as though they did not represented the main theme. Despite the fact that Hłasko (1934-1969) was twenty years younger than Kolár, the trauma of war experience imposing on the writers need of literary raw style witness to the cruelties of WW II was common for both of them (Golebiowski 2014: 97-109).

The reception of the Czech post-war poetry about the Shoah is almost absent. It is due to the fragmentariness of the Czech Shoah poetry. The critical reflection of Kolár's work in the context of the mass murder commited during the WW II is exceptional. However, the specific motifs of the Shoah were significantly examined only in recent years partially by Michal Bauer and especially by foreign reviewers: Leszek Engelking, Hanna Marciniak, and Anja Golebiowski.

The sources of the reception are partly period reviews (included antisemitic periodicals). It can have the form of a homage or obituary; exceptionally expressed by a (cryptic) poem (Halas about Orten). Another modus is critical, commemorative comments in editions. A contemporary witness (e.g. diary; exceptionally a memory of the audience - Pick) may also be plausible. 
Very valuable sources of the reception of the Shoah literature - regarding not only the Czech writers - are Jewish periodicals. One of them, "Židovská ročenka", which has been published since 1954, often introduces literary works of Jewish or non-Jewish authors writing about the Shoah (Ota Reich, Pavel Friedmann, Karel Fleischmann, Pavel Fischl, Dagmar Hilarová, Vladimír Kafka or František Halas, Jaroslav Seifert, Jan Skácel, Karel Křepelka etc.). However, one may usually find only poems published with a brief piece of information on the author's life and work.

\section{Literature}

Anonymous, 1941, “Árijský boj” No. 33, 23.08., p. 5.

Balík Š., 2016, Czech Bystanders Writing Poetry about the Shoah. Different Ways of Poetic Languages in the First Post-War Literary Reactions, in: Der Holocaust in den mitteleuropäischen Literaturen und Kulturen: Probleme der Poetisierung und Ästhetisierung, ed. R. Ibler, Stuttgart, pp. 129-144.

Bauer M., 2001a, Kolářovy způsoby zachyceni dějin bolesti a hravosti, "Tvar” No. 5, p. 23.

Bauer M., 2001b, Jiři Kolár̆: Očitý svědek v zemi mrtvých / Očitý svědek ze země mrtvých, "Tvar" No. 14, pp. 6-7.

Bauer M., 2005, Kolářovy dějiny lidstva jako dějiny bolesti a hravosti, in: J. Kolář, M. Bauer, Z každého z nás postupem let néco mizí. Rozhovor s Jiřim Kolářem, Praha, pp. 33-55.

Bonn H., 1947, Dílo Hanuše Bonna, Praha.

Brabec J., 1966, A zaklínám svou noc, která se přibližuje, "Literární noviny” No. 5, p. 5.

Brabec J., 2009, Antisemitská literatura v době nacistické okupace, in: J. Brabec, Panství ideologie a moc literatury. Studie, kritiky, portréty (1991-2008), Praha, pp. 167-195.

Burda V., Moldanová D., Steklač V., Karfík V., 1967, Osmá konfrontace, "Sešity pro mladou literaturu" No. 10, pp. 49-50.

Černý V., 1941, Torzo..., "Kritický měsíčník” No. 8, pp. 293-296.

Černý V., 1945, Básnický profil Jiřího Ortena,"Kritický měsíčník” No. 8, pp. 196-206. [Červinka J.] J.Č., 1947, Zmařený talent, in: Ohnice. Sborník současné literatury. II., eds. K. Bednář, J. Červinka, Praha, pp. 50-52.

Daniel J., 1947 Tíha, in: Ohnice. Sborník současné literatury. II., eds. K. Bednár̆, J. Červinka, Praha, p. 35.

Daniel J., Toman M. (eds.), 1998, Mé myšlenky se velice nepodobaji dýmu, Praha.

Engelking L., 2007, Laleczki na sprzedaż. Zabawa w Holokaust i handel z Holokaustem, in: Holokaust v české, slovenské a polské literature, ed. J. Holý, Praha, pp. 79-94.

Fischl V.,1943, Mrtvá ves, Londýn. 
Fischl V., 1945 Mrtvá ves, Litoměřice.

Flach M., 1997, Ohlédnutí z veliké dálky, [Praha].

[Flach M.], 1987-1988, Terezín , “Židovská ročenka 5748”, Praha, p. 137.

Fried N., 1945, Bratr Jan, [Havlíčkův Brod].

Frynta E., 1990, Bytostný básník Jiři Kolář, in: J. Kolář, Prométheova játra, Praha, pp. 203-216.

Golebiowski A., 2014, Der Holocaust und seine kulturellen Folgen. Reflexe des Holocausts im Oeuvre von Jiř́ Kolár̆ und Marek Hlasko, in: Reprezentacje Shoah w literaturze i filmie w Europie Środkowej: lata powojenne, eds. G. Gazda, M. Leyko, P. Rutkiewicz, Acta Universitatis Lodziensis. Folia Scientiae Artium et Litterarum 11 , pp. 97-109.

Goral J., 1942, Dvojí nástup. Básně. 1939-1941, Londýn.

Gottlieb F., 1946, Dvoji nástup, Praha.

Gross N., 1993, Poeci i Szoa. Obraz Zagłady Żydów w poezji polskiej, Sosnowiec.

Grossman J., 1991, Horečná bělost Jiřiho Koláře, in: J. Grossman, Analýzy, Praha, pp. 364-377.

Hájková L., 1946, Balady zatracencủ, Praha.

Halas F., 1941, Za básníkem, "Kritický měsíčník” No. 7, pp. 264-266.

Halas F., 1957, Za Jiř́m Ortenem, in: F. Halas , Básně, Praha, pp. 264-266.

Heřman Z., 1967, Kritický metr na metr knih, “Orientace” No. 2, pp. 90-93.

Hilarová D., 1968-1969, Aby neslyšeli plakat zemi; Karlův most. 1941, “Židovská ročenka 5729", Praha, pp. 117-118.

Hilarová D., 1966, Hundert Farben hat der Regenbogen: Gedichte, trans. R. Iltis, G. Deicke, Berlin.

Hilarová D., Diekmann M., [1980], Ik heb geen naam, trans. O. Krijtová, M. Diekmann, [Den Haag].

Hilarová D., 2010, Nemám žádné jméno, [Praha].

Hilarová D., 2012, Nemám žádné jméno, Praha.

Hošíková M., 2009, Motivy židovství v poezii Michala Flacha a Zena Kaprála, bakalářská práce, Brno, <http://is.muni.cz/th/215692/ff_b/>, 24.03.2016.

Holý J., 2011, Židé a šoa v české a slovenské literatuře po druhé světové válce, in: Šoa $v$ české literatuře a v kulturní pamèti, ed. J. Holý, Praha, pp. 7-65.

Ibler R., 2014, Balladengedichtung im Angesicht des Holocaust: Libuše Hájkovás Zyclus Balady Zatracencu, in: Reprezentacje Shoah w literaturze i filmie w Europie Środkowej: lata powojenne, eds. G. Gazda, M. Leyko, P. Rutkiewicz, Acta Universitatis Lodziensis. Folia Scientiae Artium et Litterarum 11, pp. 25-35.

Karfík V., 1994, Jiři Kolár, Praha

Keff B. (ed.), 2012, Tango łez śpiewajcie muzy. Poetyckie dokumenty Holokaustu, Warszawa.

Kolář J., 1966, Vršovický ezop, Praha.

Kostroun K., 1966, Znamení básníka, "Plamen” No. 2, pp. 145-146.

[Kryštofek O.] ok, 1946, Další z koncentračních táborů, "Mladá fronta" No. 120, 24.05., p. 4. 
Marciniak H., 2014, "Píši tyto řádky a prosím Boha, aby se dostaly do pravých rukou...”. Jiř́ Kolář - Tadeusz Różewicz: poetika sekundárního svědectví, "Slovo a smysl" No. 21, pp. 214-239.

Milota K., 1967, Interview se sebou o Jiřim Kolářovi, "Plamen” No. 6, pp. 97-100.

Orten J., 1947, Dílo Jiřiho Ortena, Praha.

Orten J., 1993, Zákazy, in: J. Orten, Spisy II. Žihaná kniha, Praha, p. 225.

Orten J., 1995, Spisy IV. Knihy veršü, Praha,

Pešat Z., 1991, Jaroslav Seifert, Praha.

Pick J.R., 1966, 7 kytic pro buvola, Praha.

Píša A.M., 1946, Dvojím hlasem, "Práce" No. 182, 9.08., p. 4.

Píša A.M., 1966, Básnický čin, "Impuls” No. 4, pp. 266-270.

Reich O., 1946, Květy terezínského ghetta, Praha.

Reich O., 1982-1983, Oběd v ghettu , “Židovská ročenka 5743”, Praha, p. 87.

Seifert J., 1965, Koncert na ostrově, Praha.

Šiktanc K., 1960, Heinovské noci, Praha.

Toman M., 2002, Revelalation of a Poet. The Discovery of Jiri Daniel, a Czech Poet of Jewish Origin, in: Jüdische Autoren Ostmitteleuropas im 20. Jahrhundert, eds. H.H. Hahn, J. Stüben, Frankfurt am Main, pp. 139-160.

Trefulka J., 1968, Vršovický ezop, "Host do domu” No. 5, pp. 62-63.

Vacík M., 1946, Malá kalvárie, Praha.

Vacík M., 1969, Hledání nové alchymie. Sto otázek o současné naší poezii (3), "Rudé právo" No. 20 (24. 1.), p. 5. 